\begin{tabular}{|ll|}
\hline & $\begin{array}{l}\text { International Journal of Advanced Engineering, Management and Science } \\
\text { (IJAEMS) } \\
\text { ISSN: 2454-1311 } \\
\text { Vol-7, Issue-4; Apr, } 2021\end{array}$ \\
& $\begin{array}{l}\text { Journal Home Page Available: } \text { https://ijaems.com/ } \\
\text { Journal DOI: } \text { https://dx.doi.org/10.22161/ijaems } \\
\text { Article DOI: https://dx.doi.org/10.22161/ijaems.74.3 }\end{array}$ \\
\hline
\end{tabular}

\title{
Development of integrated learning module on the development of Learning Devices
}

\author{
Wiwy T. Pulukadang, Sayama Malabar, Abdul Kadir Husain, Haris Pana I
}

PGSD Student, Gorontalo State University, Indonesia

Received: 15 Feb 2021; Received in revised form: 21 Mar 2021; Accepted: 03 Apr 2021; Available online: 26 Apr 2021 (C2021 The Author(s). Published by Infogain Publication. This is an open access article under the CC BY license (https://creativecommons.org/licenses/by/4.0/).

\begin{abstract}
The problems in this research are 1) How is the preparation of integrated learning tools for PGSD UNG students? 2) What is the quality of the integrated learning module developed in PGSD UNG students? This study aims to 1) describe the preparation of integrated learning tools for students majoring in PGSD UNG; and 2) Producing a quality integrated learning development module for students majoring in PGSD UNG.

The results showed that the objective conditions of integrated learning regarding the preparation of integrated learning devices in the PGSD department of UNG include, among others, lecturers who teach integrated learning courses do not discuss with each other as team teaching so that the learning outcomes of the subjects are not achieved, there are no good teaching materials so that students doing assignments correctly and copying and pasting assignments or downloading them from the internet, learning so far without submitting adequate explanations so that students without clear direction guidance, students are only asked to arrange learning devices and not discuss together the mistakes they make and lectures are not well structured. After doing research and development, the fourth semester students of PGSD Department are getting better with a positive response from students. The quality of the integrated learning module has met the predetermined aspects. The quality of integrated learning modules after being measured based on the characteristics of a quality module, there are 5 aspects. The quality of integrated learning modules is also developed based on input from validators who are media experts, material experts and linguists so that the quality of the integrated learning module is better.
\end{abstract}

Keywords-Learning Module, 4 D Development, Integrated Learning Tools.

\section{PRELIMINARY}

Republic of Indonesia Law No. 20 of 2003 concerning the National Education System (Sisdiknas) article 3 states that the objectives of national education as follows are aimed at developing the potential of students to become human beings who believe and fear God Almighty, have noble character, are healthy, knowledgeable, competent, creative, independent, and become a democratic and responsible citizen. To achieve this national education goal, every educational institution from the level of Early Childhood Education, Elementary School, Middle School, and Higher Education must design a curriculum.
The definition of the curriculum is in accordance with Permendikbud No. 3 of 2020 concerning National Higher Education Standards is a set of plans and arrangements regarding the objectives, content, and learning materials as well as methods used as new implementation of learning activities to achieve certain educational goals. Meanwhile, curriculum development is carried out by referring to national education standards to realize the goals of national education. The curriculum at all levels and types of education is developed with the principle of diversification according to the education unit, regional potential, and students. The curriculum is prepared according to the level 
of education within the framework of the Unitary State of the Republic of Indonesia with increased Faith and Piety; increase the potential, intelligence, and interest of students; diversity of regional and environmental potentials; regional and national development; to the world of work; development of science, technology, and arts; religion, the dynamics of global development; and national unity and national values.

The basic framework and curriculum structure for primary and secondary education are established by the Government. Primary and secondary education curricula are developed according to their relevance by each group or educational unit and school or madrasah committee under the coordination and supervision of the education office or district / city religious department for basic education and the province for secondary education. The higher education curriculum is developed by the higher education institution concerned with reference to the national education standards for each study program based on Law Number 12 of 2012 in article 35 paragraph 1 (Directorate General of Learning and Student Affairs, 2018: 9). The basic framework and structure of the higher education curriculum are developed by the universities concerned with reference to the national education standards for each study program.

Presidential Regulation Number 8 of 2012 concerning the Indonesian National Qualifications Framework (KKNI), and Law Number 12 of 2012 concerning higher education, encourage all tertiary institutions to conform to these provisions. The IQF is a statement of the quality of Indonesian human resources whose qualifications are based on the level of ability stated in the formulation of learning outcomes. Higher education as a producer of educated human resources needs to measure its graduates regarding the abilities possessed by their graduates (learning outcomes) which have been formulated in the IQF qualification level. The KKNI curriculum contains a set of plans and arrangements regarding graduate learning outcomes, study materials, processes, and assessments that are used as guidelines for the implementation of study programs. Planning and arranging the curriculum as a curriculum cycle has several stages, namely needs analysis, design, development, implementation, evaluation, and follow-up improvements made by the Study Program (Ornstein \& Hunkins, 2014).

Elementary School Teacher Education as a study program in higher education needs to develop the KKNI curriculum. The stages of preparing the higher education curriculum begin with the determination of the graduate profile and the formulation of Graduate Learning Outcomes (CPL), the determination of study materials and the formation of courses; as well as the preparation of the course organization matrix. The curriculum for primary school teacher education study programs refers to the Indonesian National Qualifications Framework (KKNI) and the National Higher Education Standards (SNPT). The formulation of the learning outcomes of the primary school teacher education study program is the result of workshops, symposiums, and finalization workshops that have been conducted by the PGSD Lecturer Association throughout Indonesia which started in 2012 until now.

In the learning outcomes of the Undergraduate Elementary School Teacher Education undergraduate program, the profile of the graduates is directed to produce undergraduate (S1) Elementary Education graduates who have the following expertise: 1) Educators at the primary school level who are able to plan, implement, evaluate and develop scientific based learning, character, and innovation to improve the quality of education; 2) Researchers who are able to solve learning problems and are able to produce proven learning innovations to improve the quality of education in elementary schools; and 3) Educational Practitioners and Consultants at the basic education unit level in the field of education management, extra-curricular coaches, evaluators of learning implementation, and media and learning resource developers. This profile gave birth to several course structures that could support learning in elementary schools based on the national curriculum.

Among the several courses in the primary school teacher education department are integrated learning courses. Integrated learning courses are taught with the aim of providing provision for students who are prospective teachers of integrated learning classes in elementary schools to have the knowledge, experience, and skills to plan and implement effective integrated learning. Integrated learning material includes the nature of integrated learning, curriculum analysis, and making Learning Implementation Plans along with integrated Learning Devices in elementary schools. Integrated learning is part of a group of study program courses that must be taught to students because integrated learning courses teach students to prepare Learning Implementation Plans and learning tools and are able to teach them according to the national curriculum.

Since 2010 researchers have taught integrated learning courses. However, since then lecturers who have taught integrated learning have not been maximal in carrying out lectures. This occurs for many reasons, including: 1) Lectures on the material of arranging thematic learning tools in integrated learning courses usually do not teach the practice of compiling learning systematics from the start, namely students describe the nature of integrated learning, analyze core competencies and basic competencies, map competencies, compile syllabus, compile a lesson plan 
implementation, create media, make teaching materials and assessments. However, only directly ask students to make lesson plans and teach them in front of the class without clear guidance, so that it causes students to be less skilled in compiling relevant integrated learning tools; 2) Lecturers do not have teaching materials as a guide for Integrated Learning courses, so students do not do assignments correctly and copy and paste assignments or just download from the internet.

From the above problems, the researchers developed teaching materials in the form of integrated learning modules that can answer all the problems that exist in the integrated learning course about Compiling Learning devices in the Elementary School Teacher Education Department, Gorontalo State University.

\section{MODULE DEVELOPMENT}

The module is formulated as one complete stand-alone unit, consisting of a series of learning activities designed to help learners achieve specific and operational learning objectives. Module is a form of teaching material that is packaged in a comprehensive and systematic manner, which contains a set of planned learning experiences designed to help students master specific learning goals. The minimum module contains learning objectives, learning material / substance, and evaluation. The module serves as a learning tool that is independent, so that students can learn at their own pace. According to the Ministry of National Education (2008: 20), a module is a set of teaching materials that are presented systematically so that its use can be studied with or without a teacher or facilitator.

The module optimizes learning resources while still paying attention to learners to be able to control their learning activities. The role of educators shifts from providing information to learning facilitators by providing various learning resources needed, stimulating enthusiasm for learning, providing opportunities to practice learning outcomes, providing feedback on learning progress and helping that what they learn is in accordance with the goals to be achieved.

The benefits of learning using modules according to Nasution (2010: 206) are 1). Increase the effectiveness of learning because learners can learn anywhere in groups or individually, 2). Determine and determine the learning time that is more in accordance with the needs and development of students, 3). Firmly knowing the achievement of students' competencies in stages through the criteria set out in the module, 4). Knowing the weaknesses or competencies that have not been achieved by students based on the criteria set out in the module so that they can decide and help participants to improve their learning and make remedials.
Meanwhile, the purpose of learning using modules is to reduce the diversity of students' learning capture through independent learning activities.

Module quality can refer to quality according to Nasution (2010: 217) which states that the quality of educational products is the point of view of developing learning materials, but besides that consideration of three aspects of quality namely validity, practicality and effectiveness can be used in a wider range of products.

According to Nasution, (2010: 231), validity refers to the level of intervention design based on knowledge of content validity and construct validity. Validity is a measure that shows the level of validity of an instrument or data. The principle of validity is a measurement or observation in collecting data.

\section{MODULE COMPILATION PROCEDURE}

The module development process consists of three main stages. First, determine the appropriate learning strategy and learning media. At this stage, it is necessary to pay attention to the various characteristics of the competencies to be studied, the characteristics of students, and the characteristics of the context and situation in which the module will be used. Second, producing or realizing the physical module. The components of the module content include: learning objectives, learner prerequisites, learning substances or materials, forms of learning activities and their supporting components. Third, develop assessment tools. In this case, it is necessary to make it clear that all aspects of competence (related knowledge, skills and attitudes) can be assessed based on certain predetermined criteria.

In development research, indicators to state that the implementation of the module is said to be effective can be seen in the accompanying components. Such as student learning outcomes and student activity processes. In this development research, researchers measured the effectiveness of the module from the final learning outcomes of students and the activity process of students using modules.

Module development must pay attention to the characteristics required for an effective module. According to Chomsin S.W. and Jasmadi (2008: 50), the characteristics of a good module, namely: a) Self-Instruction, b) SelfContained, c) Stand Alone, d) Adaptive, and e) User Friendly.

The module has advantages as stated by Vembriarto (1981: $25)$. The advantages of using modules in the teaching and learning process include: 
1) Overcoming the limitations of time, space and sensory power, both students and teachers.

2) Can be used appropriately and varied, such as to increase motivation or enthusiasm to learn, develop abilities to interact directly with the learning environment.

3) Allows students to measure or evaluate their own learning outcomes.

4) Students are more active in learning.

5) The teacher can act as a guide, not merely as a teacher.

6) Familiarize students to believe in themselves.

7) There is healthy competition between students.

8) Can ease the burden on teachers.

9) Learning is more effective, and evaluation of significant improvements.

10) This system can absorb children's attention so that lessons show more success when compared to lectures.

Learning to use modules has many benefits, students can be responsible for their own learning activities, learning with modules really appreciates individual differences, so that students can learn according to their level of ability, so learning will be more effective and efficient.

The module has weaknesses as pointed out by Vembriarto (1981: 25). The weaknesses of using modules in the learning process as pointed out by Vembriarto include:

1) Difficulties in students cannot be overcome immediately.

2) Not all students can learn on their own, but need the help of the teacher.

3) Not all materials can be reflected and not all teachers know how to implement learning using modules.

4) It is difficult to prepare materials and requires a lot of money in making modules.

5) There is a tendency for students not to study the module well.

Learning by using modules is also often referred to as independent learning. According to Suparman (1993: 197), states that this form of independent learning has the following deficiencies:

1) Material development costs are high, and the required time is long.

2) Determine the high learning discipline that students in general and immature students in particular may lack.

3) It requires more persistence from the facilitator to continuously monitor the student learning process, provide motivation and individual consultations whenever students need it.
Tjipto (1992: 72), also reveals several things that are burdensome for learning using modules, namely:

1) Learning activities require good organization

2) During the learning process it is necessary to hold several tests / exams, which need to be assessed as soon as possible

Based on some of the opinions above, it can be concluded that learning using modules also has several fundamental weaknesses, namely that it requires a large amount of money and requires a long time to procure or develop the module itself and requires high diligence from the teacher as a facilitator to continue monitoring. student learning process.

\section{THE NATURE OF INTEGRATED LEARNING}

Integrated learning is a teaching and learning approach that pays attention to and adapts to the level of development of students (Developmentally Appropriate Practical). In accordance with the stages of student development, student learning, the concept of learning and meaningful learning, learning activities should be carried out using an integrated learning approach. Integrated learning is a learning approach that uses a focus or theme to link several subjects so that it can provide meaningful experiences to students. Bredekamp in (Developing Appropriate Practice 1987), explains that integrated learning is a learning approach that uses a center of interest in the form of a focus or theme or concept, which functions as an integrated binder to form a new concept that is meaningful to the child's life and is relevant to the defined concept. The center of interest as the core of study should be raised from essential concepts or problems in students' daily lives. This will be very meaningful for student life. Through direct experience and connecting it with other concepts that they already have, students will be able to build their understanding of new concepts more deeply.

Based on the description above, it can be concluded that the notion of integrated learning is 1) Learning that begins with a center of interest which is used to understand symptoms and other concepts, both from the field of science itself and from the field of interest. other; 2) A way to simultaneously develop students' knowledge and skills; and 3) A learning approach.

Integrated Learning or commonly referred to as thematic learning is an approach to learning that deliberately links several aspects both within subjects and between subjects. With this integration, students will gain complete knowledge and skills so that learning becomes meaningful for students. Meaning here means that in thematic learning students will be able to understand the concepts they learn 
through direct and real experience that connects concepts in intra-subjects and between subjects.

Integrated learning is based on an approach that involves students from planning, exploring, and brainstorming and concluding. With an integrated approach, students are motivated to study and work in groups and learn from their own experiences. Furthermore, in its implementation, children can be invited to actively participate in exploring and elaborating on themes, topics or events, students learn the process and content (material) of more than one field of study at the same time. This activity of developing themes or topics or events is important in developing students' thinking skills systematically and systematically.

\section{COMPILATION OF INTEGRATED LEARNING TOOLS}

In the preparation of integrated learning tools, integrated learning displays the integration of skills, themes, concepts, and topics across the curriculum when several similarities are considered. These linkages are all used to improve overall learning and try to make connections from ideas / concepts in one subject to ideas / concepts in other subjects. In short, integration between topics / concepts both within a subject and across subjects needs to be done to achieve the goals and objectives of learning as a whole.

The preparation of the Learning Tool is carried out based on several stages, namely:

\section{A. Learning Planning}

Basically, for students integrated understanding always takes place either vertically or horizontally. Integration that is vertical takes place from grade 1 to grade 6 subject matter, even if integrated understanding takes place from Kindergarten to higher levels of education, such as secondary school. Understanding grade 1 topics / concepts is expected to be the basis for understanding class 2 topics / concepts, and so on. Thus, conceptual understanding always synergizes through integrated understanding.

In Majid, in general, the North Carolina Department of Public Instruction from Sigurdson (1981) in Sumantri (1999) suggests a number of components that should be revealed in an integrated learning format, namely: 1) Descriptive title; 2) The main / core theme or topic; 3) The reason why teachers want the benefits of using units in learning for their students; 4) Time that indicates the existence of a period; 5) The scope of discussion or material covered in the theme is at the same time related to the curriculum established both locally and nationally; 6) Objectives that refer to the established curriculum; 7) Activities; the order, variety and how it is done; 8) Learning resources; and 9) Evaluation.
The success of integrated learning is very much determined by how far integrated learning is planned and designed according to the conditions of students, interests, talents, needs, and abilities. Because the topics and concepts in the syllabus have been arranged based on these considerations, it is sufficient for the teacher to study the topic / concept in one unifying theme, then choose the actual theme and in the area of student experience.

In the implementation of integrated learning, it is necessary to do several things which include planning stages which include mapping activities for basic competencies, developing theme networks, developing syllabus, and preparing lesson plans (RPP).

\section{B. Competency Mapping}

This mapping activity is carried out to obtain a comprehensive and complete picture of all competency standards, basic competencies, and indicators of various subjects that are integrated into the chosen theme.

In conducting competency mapping according to Abdul Majid (2014) it can be done in two ways, namely:

1. Studying the core competencies and basic competencies contained in each subject, followed by identifying the basic competencies of several subjects that can be integrated. After that, make a unifying theme.

An example of the first mapping format is to describe Core Competencies and Basic Competencies into Indicators, describing the core competencies and basic competencies of each subject into indicators. In developing indicators, it is necessary to pay attention to the following matters: a. Indicators are developed according to the characteristics of students; b. Indicators are developed according to the characteristics of the subjects; and c. Formulated in operational verbs that are measurable and / or observable.

2. First determine the binding themes of cohesiveness, followed by identifying the basic competencies of several subjects that match the existing themes.

Of the two methods of mapping that are carried out, there are activities that must be carried out, namely determining the theme as a unifying tool or vehicle for the basic competencies of each integrated subject.

\section{Themes}

Thematic learning is a learning model whose development begins with determining a certain topic as a theme or central topic. After the theme is determined, then the theme is used as the basis for determining the basis of sub-themes from other related fields of study (Fogarty, 1991: in Abdul Majid, 2014).

Themes are the main thoughts or main ideas that are the subject of discussion (Depdiknas, 2007: in Abdul Majid, 
2014). Furthermore, according to Kunandar 2007 in Abdul Majid, the theme is a tool or a forum for putting forward various concepts to students as a whole.

D. Establishing a Network of Themes, Basic Competencies (KD), Competency Achievement Indicators (GPA), and Learning Objectives

After mapping, a network of themes can be created, namely linking basic competencies with unifying themes, and developing indicators of achievement for each selected basic competency. With this network of themes, it will be seen the links between themes, basic competencies, and indicators of each subject. In planning integrated learning there are several things that need to be considered, including the profile of the expected students, curriculum policies, framework and syllabus.

\section{E. Prepare a syllabus}

A syllabus is a learning plan for a particular subject / theme and includes competency standards, basic competencies, subject matter / learning, indicators, assessment, time allocation, and learning resources / materials / tools. The planning of the learning process includes a syllabus and a learning implementation plan that contains at least learning objectives, teaching materials, teaching methods, learning resources, and assessment of learning outcomes (PP Number 19 Article 20).

The syllabus is prepared based on Content Standards, which contains Subject Identity, Core Competencies (KI), Basic Competencies (KD), Main / Learning Materials, Learning Activities, Indicators, Assessment, Time Allocation, and Learning Resources. according to Abdul Majid, 1) Fill in Syllabus Identity, 2) Write down Core Competencies, 3) Write down Basic Competencies, 4) Identify Main / Learning Materials, 5) Develop Learning Activities, 6) Formulate Indicators, 7) Assessment, 8) Determine Time Allocation, 9) Determining Learning Resources.

\section{F. Preparing RPP}

The lesson plan (RPP) is a plan that describes the procedure and organization of learning to achieve a basic competency set out in content standards and has been described in the syllabus. The broadest scope of the RPP includes one basic competency which consists of one or several indicators for one or more meetings.

Especially for Integrated RPP, the definition of one basic competency for each subject. That is, in preparing an Integrated RPP, the teacher must develop a theme based on one basic competency contained in each subject that is considered relevant. RPP components are 1) Include Identity, which includes: School, Class / Semester, Core Competencies (KI), Basic Competencies (KD), Indicators, and Time Allocation; 2) Include Learning Objectives; 3)
Include Learning Materials; 4) Include Learning Models / Methods; 5) Include Learning Activity Steps; 6) Include Scientific Approach Activities; 7) Include the Media / Tools / Materials / Learning Resources; and 8) Include Assessment.

\section{G. Compiling Teaching Materials}

According to Ratumanan and Rosmiati (2019-290), the use of teaching materials in learning activities will provide great benefits for the quality of the process and learning outcomes as follows:

1. The availability of alternative learning sources that are not only relevant to the curriculum, but also relevant to the characteristics and needs of students, and can accommodate or be enriched with aspects of the context and local wisdom.

2. It is possible that learning will take place more interestingly, because presenting the context around students will generate motivation for students.

3. Teaching materials become richer because they are developed using various references.

4. Adding knowledge and experience of educators in writing teaching materials. The availability of media through teaching materials can build effective learning communication between educators and students because students have more trust in educators.

The development of teaching materials is an effort of educational units and educators to provide broader services to students in order to develop optimally. The availability of teaching materials allows students to learn learning independently, increase their knowledge, and can even encourage them to construct knowledge independently.

\section{H. Compilation of Integrated Learning Media}

The use of media in learning can generate new desires and interests, increase motivation and stimulation of learning activities, and even have a psychological effect on students (Hamalik, 1986: 88). Sudjana and Rivai (1992: 45) suggest some of the benefits of media in the student learning process, namely: (i) it can foster student learning motivation because teaching will attract their attention more; (ii) the meaning of the teaching material will become clearer so that it can be understood by students and allows for mastery and achievement of teaching objectives; (iii) teaching methods will be more varied, not based solely on verbal communication through words; and (iv) students do more activities during learning activities, not only listening but also observing, demonstrating, directing, and acting.

I. Compilation of Integrated Learning Evaluation

According to Mahrens and Lehmann in Ratumanan and Rosmiati (2019; 194), they state that evaluation is a systematic assessment of the benefits or uses of an object. 
In this sense, the term evaluation is seen as a specific assessment, namely a systematic assessment. Assessment (assessment) relates to all methods and processes of gathering evidence that shows the learning achievement of students. According to Depdinas (2008), assessment is a general term that includes all methods commonly used to assess the performance of individuals or groups of students. The assessment process includes collecting evidence that shows the learning achievements of students. In Permendikbud Number 23 of 2016, it is described that assessment is the process of collecting and processing information to measure the learning achievement of students.

\section{RESEARCH RESULTS AND DISCUSSION}

A. Preparation of Integrated Learning Tools in the PGSD Department of Gorontalo State University

The pre-research activity begins theoretically with student needs, namely by analyzing whether there is a mismatch between the student's current condition and the student's needs, and determining learning objectives. The step taken is to hold discussions with the teaching team for integrated learning courses to discuss problems that exist in integrated learning courses. From this team-teaching discussion, the authors are interested in developing a learning module, namely an integrated learning module for students majoring in PGSD UNG. The author has developed an integrated learning module which aims to be used in integrated learning courses and also aims so that students can learn independently and can also learn face-to-face with their lecturers.

The basic principles in developing this learning module are 1) Helping students focus on their learning resources, 2) Helping students prepare for independent study, 3) Have a learning plan that can be responded to optimally, 4) Contains complete learning content and is able to provide learning opportunities for students, 5) Can monitor student learning activities, and 6) Can provide suggestions and instructions as well as information on the level of student learning progress.

After conducting research on the principles of developing an integrated learning module, the researcher concluded that it was easier for students to compile a good integrated learning tool.

\section{B. Quality of Integrated Learning Module in PGSD UNG} Department.

The quality of the integrated learning module is analyzed using Semester Learning Plans (RPS), Student Activity Sheets (LKM), and Integrated Learning Modules.
For data analysis using descriptive qualitative data analysis and quantitative descriptive. Qualitative data analysis is used to describe the results of preliminary observations before designing the learning module and the results of the preparation of the learning module and to describe the suggestions that have been given by the validators, expert lecturers to perfect the learning modules that have been made. Meanwhile, quantitative data analysis is used in research on the ideal and feasibility level of the learning module which is assessed by expert lecturer validators. The results of the small group test and field trial using tabulation of the results of the respondents in the form of a percentage.

The quality of the integrated learning module is developed based on the assessment of material experts, media experts and linguists and based on the theory of the characteristics of a good learning module according to Chomsin SW and Jasmadi, namely based on self-instruction characteristics, self-contained characteristics, stand-alone characteristics, adaptive characteristics, and user-friendly characteristics.

The results showed that, the learning module that has been designed by researchers and validated by experts obtained the results in the form of a valid and reliable learning module with a conclusion that is very suitable for use. The results of the validation that have been carried out by these experts are in the form of suggestions or input accompanied by an assessment of each module. Suggestions or input from experts or panelists are processed statistically to be used as a basis for decision making whether the module is valid and reliable.

\section{DISCUSSION}

The development of Integrated Learning modules for the preparation of Learning devices for PGSD students at Gorontalo State University uses the 4 D model. The 4-D (Define, Design, Develop, and Disseminate) development research conducted by researchers has clear, systematic and directed steps making it easier for researchers to develop integrated learning modules for the preparation of learning devices. The 4-D development model consists of define, design, develop while the researchers disseminate stages are limited to the UNG campus environment due to time and cost considerations.

The Integrated learning module on development of learning devices research involves media experts, language experts for module development, while for the preparation of integrated learning tools it involves curriculum experts. After going through the validation stage, experts state that the development of an integrated learning module for the preparation of learning devices is valid. The preparation of learning tools involved fourth level students of the State University of Gorontalo PGSD. 
After being validated, the integrated learning module for the preparation of learning devices is needed by many people other than PGSD students. This module is also needed by curriculum lecturers, teachers both primary school teachers, junior high school teachers and senior high school teachers.

\section{CONCLUSION}

The objective conditions of integrated learning regarding the preparation of integrated learning devices in the PGSD department of UNG was not good. After doing research and development, the fourth semester students of PGSD Department are getting better with a positive response from students.

The quality of the integrated learning module has met the predetermined aspects. The quality of integrated learning modules after being measured based on the characteristics of a quality module, there are 5 aspects. The quality of integrated learning modules is also developed based on input from validators who are media experts, material experts and linguists so that the quality of the integrated learning module is better.

\section{REFERENCES}

[1] Balsamo Kathy. 1994. Thematic Activities for Student Portfolios. Beavercreek: Pieces of learning.

[2] Bredekamp. 1987. Development Appropiate Practice. New York :National Association for the Education of Young Children (NAEYC)

[3] Collins Gillian, Dixen Hazel, 2001. Integrated Learning: Planning Curriculum Unit. Bookshelf Stage 3.Australia : Bookshelf Publishing

[4] Clearly Pauline, Luca, Di. 1986. Learning Through an Approaches and Guildelines Integrated Curriculum. Victoria: Ministery of Education.

[5] Chomsin S. Widodo, Jasmadi, 2008. Panduan Menyusun Bahan Ajar Berbasis Kompetensi. Jakarta: PT Elek Media Komputindo.

[6] Dale, Edgar, 1969. Audio Visual Methods in Teaching, New Yorg: Holt, Rinehart and Winston Inc. The Dryden Press.

[7] Hamalik, O, 1994. Media Pendidikan, cetakan ke-7. Bandung: Penerbit PT. Citra Aditya Bakti.

[8] Hamid, Hamdani. 2013. Pengembangan Sistem Pendidikan di Indonesia. Bandung: Pustaka Setia.

[9] Heinich, Robert dkk. 1982. Instructional Media and The Technologies of Instruction. New York: John Wiley \& Sons

[10] Indrawati. 2009. Modul Pembelajaran Terpadu Di Sekolah Dasar. Jakarta: Pusat Pengembangan dan Pemberdayaan Pendidik dan Tenaga Kependidikan Ilmu Pengetahuan Alam (PPPPTK IPA).

[11] Kemdikbud, 2017. Panduan Penilaian oleh Pendidik dan Satuan Pendidikan SMP. Jakarta: Pusat Pengembangan Tenaga Kependidikan BPSDMPPMP.
[12] Majid, Abdul. 2014. Pembelajaran Tematik Terpadu. Bandung: PT. Remaja Rosdakarya.

[13] Marzano, Robert J. 1992. Dimensions of Thinking: A Framework for Curricullum and Instruction.ASCD. Alexandria:125 New Street.

[14] Mathews, Louis De Vriesdan Jean Crawford. 1989. Learning through an Integrated Curruculum: Approach abd Guidelines. Victoria: Ministry of Education.

[15] Nasution, S. 2010. Berbagai Pendekatan dalam Proses Belajar Mengajar. Cetakan kelima. Jakarta: Bumi Aksara.

[16] Ornstein, Ac dan Hunkins, F. P. 2014. Curriculum: Foundation, Principles, and Issues (Ged). New York: Person.

[17] Pulukadang, Wiwy, dkk. 2020. Integrated Learning Module Development on Department of PGSD Students. Gorontalo state University, Indonesia. IJAEMS.

[18] Pusat Kurikulum. 2002. Penjelasan Umum Kurikulum Berbasis Kompetensi. Jakarta: DEPDIKNAS.

[19] Ratumanan, T.G dan Rosmiati Imas. 2019. Perencanaan Pembelajaran. Jakarta: PT. Raja Grafindo Persada.

[20] Sukmadinata, N.S. 2000. Pengembangan Kurikulum - Teori dan Praktik. Bandung: Rosda Karya

[21] Wilson Lorraine, Malmgren David, RamageShirl. 1991. An Integrated Approach Learning, Melbourne: Thomas Nelson Australia

[22] Depdiknas. 2008. Panduan Pengembangan Bahan Ajar. diunduh pada tanggal 25 Februari 2019 Pukul 15.00 WIBTA.http://dc218.4shared.com/download/vj4M9K10/5_ PENGEMBANGAN_BAHAN_AJAR .rar?tsid=201200227-061731-a8f2e27

[23] Fajar, Setia. 2012. Pemetaan Pembelajaran Tematik. Diakses Oktober 19, 2012, dari http://fajarsetia2020.blogspot.com/2012/10/perancanganpembelajaran-terpadu.html 